\title{
Mutation Genetics of Pea (Pisum sativum L.): What Is Done and What Is Left to Do
}

\author{
Andrey Sinjushin
}

received: 13 July 2013, accepted: 15 July 2013

published online: 28 October 2013

(C) 2013 IFVC

doi:10.5937/ratpov50-4191

\begin{abstract}
Summary: Together with an outstanding practical value, garden pea (Pisum sativum L.) represents a classical model object for studies on ontogeny of compound inflorescence, compound leaf, zygomorphic flower and nodulation. Both crop improvement and developmental researches become possible, as a range of natural variation was broadened by mutations. A contemporary state of mutation genetics in pea is reviewed with special reference to genetics of ontogeny and practical value.
\end{abstract}

Key words: genetics, mutation, ontogeny, peas, Pisum sativum

\section{Introduction}

The three entities of the topic, genetics as a science, mutation genetics and genetics of pea, appeared together and simultaneously in the classic experiments of Gregor Mendel (1866). As everybody knows, Mendel himself studied the inheritance of seven traits, the variation of which resulted from the spontaneous mutations. When discussing any kind of inherited variation, we deal with results of mutations that led to an origin of novel alleles. However, here we mostly consider mutations of "non-anonymous" origin, i.e. ones induced artificially or discovered in cultivated material as spontaneous variations.

As we may say using contemporary terms, the classic work of G. Mendel was dedicated to inheritance of seven developmental mutations. All forms that he used for crosses were available on market, so we may see that inherited monogenic ("Mendelian") anomalies of development were used for a crop improvement long before terms "gene" and "mutation" appeared. To date, the molecular basis was uncovered only for four Mendelian mutations out of seven (Reid \& Ross 2011). Some of them are still of an intense agricultural interest discussed below.

A. Sinjushin*

M.V. Lomonosov Moscow State University, Biological Faculty, Genetics Dept, 119991, Moscow, 1-12 Leninskie Gory, Russia

e-mail: asinjushin@mail.ru
During long history of studies on the pea genetics, few efforts were made to summarize all known mutations. As a result, steadily growing lists appeared, such as works (Blixt 1972, Makasheva 1984, Murphet \& Reid 1993, etc.). Obviously, it is waste of both time and word limit to reproduce these reviews, so in given paper we would focus mostly on two aspects of mutation genetics in pea: use of mutants to uncover the regulatory mechanisms of some developmental processes and the practical application of mutants in pea improvement.

If overlook the contemporary state of knowledge of different mutations in pea, one might notice few tendencies. The most part of 20th century brought the descriptions of few hundreds of different mutations, many of which were localized on a genetic map. Many synonyms in designations of mutants availablein different germplasm collections arose. However, most of these mutations were not characterized on molecular level. The most upto-date review of known mutations, with most of binomials unified, is PGene Pisum Gene List available online (PGene 2013).

Some statistics on described mutations in pea may be illustrative but hardly triumphant, and let these data outmode soon. The number

Acknowledgements:

The review includes the results obtained with a partial support from Russian Foundation for Basic Researches (project no. 12-04-01579) and the program of Rus. Acad. Sci. "Leading Scientific Institutions" (project no. NS-376.2012.4). 
of known and characterized mutations (except for provisional and poorly characterized) is strongly disproportional for different categories. For example, 66 mutations influencing the leaf development are listed in PGene database. Surely, this list is not covering all known mutations, as some of descriptions are given in languages other than English (e.g. (Zelenov et al. 2008)). Among these 66, only four underlying genes were identified on molecular level. The number of known mutant alleles is remarkable for these four: 5 for CRISPA, 9 for COCHLEATA, 10 for APULVINIC, and 18 (sic) for TENDRIL-LESS (PGene 2013). Role of most of these genes is discussed below. The other leaf regulators listed in a database are known as having one (rarely two) mutant allele; most of them were described and included in collections long before gene identification itself became possible. An impression arises, that only a decision to clone certain gene may provoke searching for allelic mutants in different collections. On the other hand, the variability of the mutant alleles of the identified genes ensures us that existing germplasm collections may include forms mutated in almost all known genes.

The problem is that most of projects dealing with induced mutagenesis are focused on certain aspects (e.g. nodulation) while mutants with other features, if arise, remain unnoticed, except for the most showy ones. For example, study of induced mutants of pea and sweetclover by Kneen \& LaRue (1988) demonstrates that numerous mutants of expected phenotype arise in large samples treated with mutagenic factors. As for other mutations (e.g. in sweetclover), only statistics on the chlorophyll and anthocyanin defects is presented, i.e. on the most remarkable traits. No wonder that nothing or vanishingly little is known on genetics of such hard-to-detect features as stomatal or pollen development in pea: these features cannot be found, if not searching specially for them. For comparison, few genes affecting a stomatal ontogeny are already known in Arabidopsis (Nadeau \& Sack 2002).

The study of (Moreau et al. 2012) also included fast neutron mutagenesis that resulted in a production of four allelic mutations in a single gene involved in flower pigmentation, $B$, and finally crowned with its identification. It is not surprising that during more than 150 years of genetic studies in pea recurrent mutations arose in the same genes, and carriers of these mutations are available in different germplasm collections. Actually, one who searches for certain mutations finds them - either in the existing collections or via experimental induction of new inherited abnormalities.

To get more information on novel genes in pea, the projects on induced mutagenesis need to be accompanied by detailed analysis of all possible phenotypic features, as many mutations seem to be simply missed - that is the most serious reason for such disproportion in number of discovered mutations affecting "noticeable" versus "cryptic" features in pea. Until now, pea remains awaiting for whole-genome sequencing, but the already existing sequences of related legumes (Medicago truncatula, Lotus japonicus, and especially recently sequenced chickpea, Cicer arietinum (Varshney et al. 2013)) would make this aim much easier.

We will hereafter overview some aspects of the mutation genetics in pea with special reference to genetic control of an ontogeny and, where possible, a practical value of pea developmental mutants. The features of regulation that have some specificity in pea compared with other model objects are concerned.

\section{Flower structure}

Together with Antirrbinum majus (Plantaginaceae, formerly Scrophulariaceae), pea comprises the model object for analysis of flower zygomorphy control. To date, few genes were identified which, if mutated, alter papilionate flower morphology - KEELED WINGS $(K)$, LOBED STANDARDI (LSTI) (Wang et al. 2008), LATHYROIDES (Zhuang et al. 2012). The genes ELEPHANT EAR-LIKE LEAFI and 2 (ELE1,ELE2) have been precisely localized but not cloned yet ( $\mathrm{Li}$ et al. 2010). Mutants $k$ have homeotic replacement of wings with keel petals, flag (standard) bears lateral notches in flowers of $l s t$ mutants. Mutations in genes ELE cause formation of bilaterally symmetrical wings and keel petals together with enlarged stupules.

Key regulators of floral organ identity (genes of ABC-model, see (Weigel \& Meyerowitz 1994)) have also been cloned in Pisum and appeared homologous to such regulators in Arabidopsis. These are STAMINA PISTILLOIDA (STP), the pea ortholog of PISTILLATA (Taylor et al. 2001, Berbel et al. 2005); PETALOSUS (PE), probable C-class regulator (Ferrandiz et al. 1999), and PEAM4 homologous to APETALA1 (Berbel et al. 2001). Although their function is conserved in different angiosperms, these genes have some specificity of expression in zygomorphic papilionate flower. For example, flowers in mutants stp- 1 have only two adaxial stamens of an outer whorl converted into carpelloid structures, while other stamens develop normally (Taylor et al. 2001).Such homeotic mutants with supernumerary carpels can provide some insight into problem of origin 
of multicarpellate flower normally developing in some Fabaceae (e.g. mimosoids Archidendron and Inga p.p.; (Sinjushin 2013)).

The surprisingly little number of flower color phenotypes is known in pea (summarized in (Moreau et al. 2012)). If consider its close relationship with sweet pea (Lathyrus odoratus) with its outstanding variability of the flower colors, one may expect more genes which regulate this habit in garden pea. One of the Mendelian mutations, $a$, provides absence of anthocyanins in stem, seed coat, leaves, pods and corolla. Most of known pea cultivars are homozygous at $a$, except for forage ones. The gene $A$ has been characterized on molecular level as encoding the basic helix-loophelix transcription factor (Hellens et al. 2010). The group of researchers who cloned gene $A$ successfully exploited the available data on genome sequence of related legume, alfalfa (Medicago truncatula). The numerous allelic mutations $a$ seem to be the only floral mutations having any practical value, while other (especially homeotic abnormalities) usually reduce fertility and still have no application, even as ornamental forms.

\section{Pod and seed features}

Actually, little is known on genetics of fruit (pod) development and embryogenesis of pea. Numerous genes are known which by any means regulate a pod shape but they also are not identified (PGene 2013).

The wrinkled (starch-deficient) seeds represent the feature, which clearly delimits all existing pea cultivars into grain (with round seeds), and vegetable (with wrinkled seeds) ones. The feature is caused by few mutations (PGene 2013). Among them, the recessive mutation rugosus $(r)$ was the first Mendelian mutation identified on molecular level (Bhattacharyya et al. 1990).

The perspective of significant improvement of pea cultivars appeared after discovery of mutation development of funiculus (def). As detailed histological analysis of mutant phenotype demonstrated, no abscission layer was formed on a boundary between a funicle and a seed hilum (Ayeh et al. 2009). Introduction of this feature into the genotype of highly productive cultivars seems promising for breeding forms with reduced seed losses after ripening and during harvest. To date, few cultivars have been bred which bear def in their genotypes - e.g. Batrak by All-Russian Research Institute of Grain Legumes and Groat Crops (Orel, Russia).

The most variable seed feature is a color of testa, and many mutations and naturally occurring genetic determinants were described, which influence this trait (PGene 2013). Seed testa color usually correlates with anthocyanin pigmentation of a flower and other aerial organs. Most of contemporary cultivars produce seeds with a colorless testa prone to imbibing water. The latter peculiarity makes seeds of a garden pea free from hibernation period, which is typical for wild-growing legumes of temperate region due to thick water-impermeable testa. Exemption from this character was one of the most significant steps on the way of crop domestication. However, a testa thickness is not easy to study and little is known on genetic control of this trait.

At least two genes, $P$ and $V$, contribute to a formation of a lignified layer on an inner surface of a mature pod. As mutations in these genes cause development of an unlignified pod, they are of great significance for breeding of vegetable (marrow) cultivars with edible pod valves. Mutation $p$ seems to be the one studied by Mendel but remains uncharacterized on molecular level (Reid \& Ross 2011). The genetic control of pod dehiscence is of great interest, as an indehiscent pod represents one of the basic demands to cultivated legumes. Most of cultivated Fabeae species (pea, faba bean, and lentils) possess fruit resistant to dehiscence, and acquisition of such pod seems to result from ancient mutations kept in gene pools since the infancy of agriculture. However, the feature is difficult to study and seems to be inherited as polygenic quantitative trait (Weeden et al. 2002).

\section{Stem and inflorescence architecture}

The mutations affecting stem and inflorescence development in pea are of twofold interest. On one hand, pea still remains the most convenient object for study of developmental regulation of compound inflorescence. On the other hand, many of such mutations may appear valuable for breeding cultivars with shortened vegetation period and higher production. The long flowering phase, when seed ripening occurs simultaneously with a formation of new flowers, remains one of the most negative features of many contemporary cultivars of pea. Actually, difference between potential seed productivity and real amount of harvested seeds is too significant. Many of cultivars with indeterminate growth are being cropped after ripening of fruits at first two nodes while an upper part of inflorescence often remains in anthesis. That is why the necessity to limit flowering phase is one of the most evident in pea breeding.

At least one mutation that leads to the preliminary termination of an anthesis is known, 
namely determinate (det) (Makasheva \& Drozd 1987). The mutants develop 1-5 lateral (axillary) racemes, usually two-flowered, and then produce terminal inflorescence. The whole stem apical meristem becomes converted into meristem of an inflorescence, as it normally happens in some other herbaceous legumes (e.g. Galega). Such ontogenic switch is unusual for pea and other members of Fabeae tribe, so the phenotype of such determinate forms was studied precisely (Singer et al. 1990, 1999, Sinjushin 2011). It was demonstrated that det plants also produce terminal flowers on axillary racemes the latter sometimes becoming bracteous. The $D E T$ gene appeared homologous to TERMINAL FLOWER 1 of Arabidopsis (Foucher et al. 2003).

Usage of det mutation in pea breeding turned out to be complicated enough, as DET is tightly linked with $R$, both on linkage group (LG) VII. At least two det alleles independently obtained on different background ( $\operatorname{det} R$ and $\operatorname{det} r$ ) were used in Russia as initial material in breeding of grain and vegetable cultivars with determinate inflorescence growth (Kondykov et al. 2006).

One more type of inherited growth limitation is caused by the mutation determinate habit (deh). Although it has been already used for breeding of few Russian cultivars (e.g. Flagman, Batrak), little is known on an inheritance and a phenotypic manifestation of this abnormality. The mutant plants produce less axillary inflorescences than the control ones. The stipules in upper part of stem become strongly reduced and scale-like, with features of senescence. Possibly the reduction of stipule area itself is sufficient for apical growth cessation but the feature is unstable and in humid condition plant may produce both anomalous and normal stipules. The mode of inheritance of this mutation also seems somewhat diverse from recessive, as $\mathrm{F}_{1}$ hybrids from crosses between deh and $D E H$ plants exhibit intermediate features, while $\mathrm{F}_{2}$ progeny often deviates from the expected 3:1 ratio (Belyakova \& Sinjushin 2012). Gene(s) involved in a development of such determinacy remain(s) unidentified.

The certain alterations in inflorescence morphology are also observed in case of a stem fasciation. The first description of fasciated peas was given in 16th century (White 1948), while the first data on inheritance of fasciation in pea were obtained by G. Mendel who used specific epithet "Pisum umbellatum" to designate fasciated forms. To date, minimum five genes are known which cause more or less expressed stem fasciation when mutated (Sinjushin \& Gostimskii 2007). As in all plants, fasciation in pea results in ridge- like anomalous enlargement of the shoot apical meristem (SAM) which in its turn causes formation of flattened shoot with aberrant phyllotaxis and axillary racemes clustered on the top (Sinjushin \& Gostimsky 2006). Some of these genes have been identified on molecular level and appeared homologous to genes of Arabidopsis, which also participate in a negative regulation of SAM sizes (Krusell et al. 2011). Although a genetic control of SAM activity seems very conservative in the evolution of plants, legumes are characterized with some interesting peculiarities. Flowers of fasciated pea (and other legumes, reviewed in (Sinyushin 2010)) mutants remain normal, while in fasciated plants of Arabidopsis both stem and floral meristems become affected. The axillary raceme becomes terminated with anomalous flower in some fasciated plants (Sinjushin 2011). More, certain similarity is observed in a genetic regulation of SAM activity and symbiotic nitrogen fixation (nodulation), the latter phenomenon being a specific feature of Fabaceae. Two fasciated pea mutants, sym 28 and nod4, were identified as hypernodulating (i.e. with unusually high number of symbiotic nodules). Gene SYM28 was identified as a homolog of CLAVATA2 of Arabidopsis, which encodes the membrane receptor-like kinase protein, this class of proteins being one of the most widespread in regulation in plants, so involvement of same genes in control of both SAM activity and nodulation is expected, although unique for legumes (Krusell et al. 2011). Details of genetic control of nodulation in pea together with description of known symbiotic mutants are available in specialized review (Borisov et al. 2007).

A value of fasciated mutants for pea breeding is debatable. Although the fasciated plants produce more fruits and seeds than normal ones and ripening occurs more or less synchronously, a huge mass of pods in an upper part of stem predisposes the whole plant to lodging. It is connected with fact that pea stem is normally very thin and weak at a basement, so lodging is usual and common problem for many cultivars. Few fasciated pea cultivars were historically bred (Rosacrone in German, Buława in Poland, Shtambovyi-2 in USSR etc.) but now have little or no importance. Possibly more promising are double mutants det fa with the weakly fasciated determinate stem (so-called "lupinoid" forms, see (Sinjushin \& Gostimsky 2006)). Such morphotypes are in scope of an active investigation in Russia (Kondykov et al. 2006).

A genetic control of the flower number in an axillary raceme is unclear. In early works of $\mathrm{H}$. Lamprecht (1947) a many-flowered (compared with normally two-flowered) raceme was 
interpreted as a result of distortion in two polymeric genes, $F N$ and $F N A$. A monogenic control of such habit connected with gene NEPTUNE was also described (Singer et al. 1999).

Numerous genes are known which regulate a gibberellic acid (GA) balance in pea and hence participate in stem elongation. This aspect was precisely studied in series of works by J.J. Ross and J.B. Reid with coauthors; some of these genes were identified (reviewed in (Ross et al. 1997), see also other works by these authors). One of the most known mutations causing a dwarfism in pea is $l e$, seemingly the one studied by G. Mendel. Normally gene $L E$ encodes gibberellin $3 \beta$-hydroxylase (Lester et al. 1997). Mutants le have a stem with strongly shortened internodes, and this abnormality was used for breeding of cultivars resistant to lodging. Actually, almost all of contemporary cultivars have a shortened stem.

\section{Genetics of compound leaf morphology}

A pea comprises the traditional model object for studies on compound leaf development. To date, dozens of mutations are known which affect an ontogeny of either the whole leaf or its parts (stipules, rachis, leaflets or tendrils), and descriptions of novel leaf mutations appear literally every year. Most of them remain uncharacterized on a molecular level.

The key regulator of leaf (and also flower and inflorescence) development in pea is UNIFOLIATA (UNI). It governs the complexity of leaf: homozygotes in alleles with different severity produce either unifoliolate leaf (uni) or leaf with a preliminary formation of a terminal leaflet instead of distal leaf structures $\left(u n i^{\text {tac }}\right)$. At least two negative regulators of leaf complexity are known, viz. AFILA ( $A F$; mutants af produce a strongly ramified leaf rachis, all termini ending with tendrils) and MULTIFOLIATE-PINNA (MFP; distal part of leaf in $m f p$ plants produces secondary axes) (Marx 1987, Mishra et al. 2009). Few genes define type of a leaf organ, either a leaflet or a tendril. Mutation af causes a formation of tendrils exclusively, while mutants tendril-less $(t l)$ bear leaflets only, as in leaves of vast majority of etendrillous legume genera (e.g. Astragalus). The partial leaflet-to-tendril transformation is observed in mutants $t / 2$ and insecatus (ins) (Berdnikov \& Gorel 2005, Kumar et al. 2010).

Gene $U N I$ is under a negative control of few genes, the main of them are $A F, T L$ and also COCHLEATA (COCH). The latter one suppresses $U N I$ expression in stipules and other organs (Gourlay et al. 2000, Sharma et al. 2012), and stipule phenotype of some coch mutations is extremely remarkable: both stipules become pinnate and leaf-like. Similar homeotic stipuleto-leaf transformation is observed in a normal ontogeny of some caesalpinioid Fabaceae, such as Delonix regia (but not other Delonix species), Caesalpinia bonduc, and Peltophorum africanum (Sattler 1988, Sharma et al. 2012), so variations in an expression of $\mathrm{COCH}$-like genes might contribute to polymorphism of normal ontogeny in Fabaceae. Except for a leaf phenotype, coch mutants are also characterized with anomalous flower and inflorescence structure together with an unusual proliferation of root nodules. Gene $\mathrm{COCH}$ was recently identified as a pea homolog of Arabidopsis genes BLADE-ON-PETIOLE (BOP1, 2) (Couzigou et al. 2012).

We have briefly summarized only the facts dealing with most precisely characterized leaf mutations in pea. The listed mutations are "peaspecific" or, more generally, "legume-specific", as they distort the ontogeny of a compound leaf typical for most Fabaceae. Except listed genes, some are known which regulate more basic aspects of leaf patterning and hence have homology with known genes of other model objects. For example, gene CRISPA (CRI) is known which demarcates an abaxial side from adaxial. It was characterized as ortholog of PHANTASTICA of Antirrbinum majus and ASYMMETRIC LEAVESI of Arabidopsis thaliana (Tattersall et al. 2000). The function of abaxial-adaxial patterning is one of the basic in leaf development and hence orthologous genes are expected to persist through a plant evolution. However, in pea gene $C R I$ also possesses some specificity connected with compound leaf development; it is proposed to delimit zone of a stipule initiation (Tattersall et al. 2000).

Some of listed leaf morphotypes are of special value in a pea breeding (Mikić et al. 2011). As pea often suffers from lodging, many of cultivars are characterized with a dwarf stem $(l e)$ and "tendrilled" leaves (af), such as Filby (UK), Batrak (Russia) etc. The supernumerary tendrils enable more efficient scrambling and hence reduced lodging. Unfortunately, af plants have reduced photosynthetic area, so different efforts are made to combine both increased scrambling capacity and an effective assimilation. Few perspectives of such improvement are visible. Some alleles of af cause development of so-called "semi-leaflesst" phenotype with a pair of normal leaflets preceding ramified rachis of typical af leaf (Ambrose 2004).

Two different recombinants are known in pea that possess promising leaf types. One of them is af unitac bearing an unusual phenotype with strongly 
ramified rachis, leaflets on long petiolules and intermediate tendril-to-leaflet organs (Prajapati \& Kumar 2002). Such phenotype was called "chameleon" and evaluated as very prospective in pea improvement. Such genotype has already been used in Russia for breeding of cv. Spartak (2009) (Amelin et al.2011). Recently a novel mutation was recorded in pea, which seems to prevent separation of distal leaf organs: a lobate lamina develops instead of distal tendrils. This mutation was designated as tendrilled acacia-A $\left(\operatorname{tac}^{\mathrm{A}}\right)$ (Zelenov et al. 2008). Double recessive homozygotes $a f t a c^{A}$ develop very unusual leaf phenotype with strongly ramified rachis (as in af), pinnate lobed leaflets and tendrils, often with organs of a hybrid habit. It has much higher photosynthetic activity than af forms together with an improved scrambling capacity, so it can be also used for breeding of highly productive and lodging-resistant cultivars (Avercheva et al. 2012).

\section{Nodulation}

The process of nitrogen fixation by bacteria that form symbiosis with plants plays the important role in both biosphere homeostasis and agriculture. Most of Fabaceae members form symbiotic root nodules, and this process is of great interest. To date, numerous genes are known which control this process directly or implicitly. The genetic control of nodulation is a subject of special reviews (Borisov et al. 2007, Shtark et al. 2011). Surely, regulation of symbiotic nitrogen fixation can be subdivided into few stages, such as recognition of bacterial cell, nodule proliferation, bacteroid differentiation etc. (reviewed by Borisov et al. 2007). Dozens of mutations are known which distort different steps of this interaction. No wonder that regulatory pathways controlling nodulation interact with other developmental processes in legumes. Some of mutants defective in nitrogenfixing symbiosis are also characterized with other structural abnormalities, such as fasciation (sym28, nod4), floral and leaf malformations (coch) etc. (see above). Numerous genes were localized on a genetic map and even identified on molecular level, often through an intermediary of legumes with already sequenced genome (Lotus japonicus and Medicago truncatula).

Although genetics of nodulation seems to be more or less precisely dissected, the induced mutants with altered nodulation capacity comprise certain difficulties for breeding. To date, the cultivars or wild-growing accessions of pea with naturally high symbiosis effectiveness seem more promising in breeding than induced mutants.

\section{Conclusions}

Finishing given brief review of some aspects of mutation genetics in pea, we may conclude the following. To date, multitude of pea mutants are known and available for research. Studies on these forms seem promising for uncovering such unique and interesting aspects of plant development, as compound leaf and inflorescence ontogeny, formation of a monosymmetric flower, genetic control of symbiotic nitrogen fixation (nodulation) etc. Although physiological and developmental features of these mutants remain actual and challenging, better understanding of precise mechanisms requires identification of certain genes. This aim is still to be achieved, and pea, although being the most traditional model species in genetics, remains in arrears as compared with Arabidopsis and snapdragon. Surely, this gap can be bridged with usage of genomic and postgenomic approaches. Identification of key regulatory genes comprises not only fundamental value but also has great practical interest. The directed mutagenesis and purposeful correction of gene expression based on knowledge of certain genes' structure can serve for further improvement of this valuable crop culture. 


\section{References}

Ambrose, M. (2004). A novel allele at the Afila (Af) locus and new alleles at the Tendril-less (Tl) locus. Pisum Genet, 36, 1-2.

Avercheva, O.V., Sinjushin, A.A., \& Zelenov, A.N. (2012). A spontaneous mutation in a semi-leafless pea cultivar restores leaflet formation and improves photosynthetic function. In: VI International Conference on Legumes Genetics and Genomics. Program and abstract book. 391.

Amelin, A.V., Kostikova, N.O., Kondykov, I.V., Panarina, V.I., Uvarova, O.V., \& Bobkov, S.V. (2011). Seed quality in pea cultivars with different morphotypes. Vestnik OrelGAU, 28, 86-90. In Russian.

Ayeh, K.O., Lee, Y., Ambrose, M.J., \& Hvoslef-Eide, A.K. (2009). Characterization and structural analysis of wild type and a non-abscission mutant at the development funiculus (Def) locus in Pisum sativum L. BMC Plant Biol, 9, 76.

Belyakova, A.S., \& Sinjushin, A.A. (2012). Phenotypic expression and inheritance of determinate habit (deh) mutation in pea ( $P i$ sum sativum L.). In: VI International Conference on Legumes Genetics and Genomics. Program and abstract book. 353.

Berbel, A., Navarro, C., Ferrandiz, C., Canas, L.A., Madueno, F., \& Beltran, J. (2001). Analysis of PEAM4, the pea API functional homologue, supports a model for $A P 1$-like genes controlling both floral meristem and floral organ identity in different plant species. Plant Journal, 25(4), 441-451.

Berbel, A., Navarro, C., Ferrandiz, C., Canas, L.A., Beltran, J., \& Madueno, F. (2005). Functional conservation of PISTILLATA activity in a pea homolog lacking the PI motif. Plant Physiology, 139(1), 174-185. doi:10.1104/pp.104.057687

Berdnikov, V.A., \& Gorel, F.L. (2005). A mutation, $t l 2$, in pea (Pisum sativum L.) affects leaf development only in the heterozygous state. Theoretical and Applied Genetics, 110(6), 10861091. doi:10.1007/s00122-005-1929-4

Bhattacharyya, M.K., Smith, A.M., Ellis, N.T.H., Hedley, C., \& Martin, C. (1990). The wrinkled-seed character of pea described by Mendel is caused by a transposon-like insertion in a gene encoding starch-branching enzyme. Cell,60(1), 115-22.

Blixt, S. (1972). Mutation genetics in Pisum. Agri Hort Genetica, 30, 1-293.

Borisov, A.Y., Danilova, T.N., Koroleva, T.A., Kuznetsova, E.V., Madsen, L., Mofett, M., . . Rozov, S.M. (2007). Regulatory genes of garden pea (Pisum sativum L.) controlling the development of nitrogen-fixing nodules and arbuscular mycorrhiza: A review of basic and applied aspects. Appl Biochem Microbiol, 43(3), 237-243. doi:10.1134/S0003683807030027

Couzigou, J., Zhukov, V., Mondy, S., Abu, H.G., Cosson, V., Ellis, N.T.H., . . Hofer, J. (2012). NODULE ROOT and COCHLEATA maintain nodule development and are legume orthologs of Arabidopsis BLADE-ON-PETIOLE genes. Plant Cell, 24(11), 4498-4510.

Ferrandiz, C., Navarro, C., Gomez, M.D., Canas, L.A., \& Beltran, J.P. (1999). Flower development inPisum sativum: From the war of the whorls to the battle of the common primordia. Dev Genet, 25(3), 280-290. doi:10.1002/(SICI)1520-6408(1999)25:3<280::AID-DVG10>3.0.CO;2-3

Foucher, F., Morin, J., Courtiade, J., Cadioux, S., Ellis, N., Banfield, M.J., \& Rameau, C. (2003). DETERMINATE and LATE FLOWERING are two TERMINAL FLOWERI/ CENTRORADIALIS homologs that control two distinct phases of flowering initiation and development in pea. Plant Cell, 15(11), 2742-2754. doi:10.1105/tpc.015701

Gourlay, C.W., Hofer, J.M.I., \& Ellis, N.T.H. (2000). Pea compound leaf architecture is regulated by interactions among the genes UNIFOLIATA, COCHLEATA, AFILA, and TENDRIL-LESS. Plant Cell, 12(8), 1279-1294.

Hellens, R.P., Moreau, C., Lin-Wang, K., Schwinn, K.E., Thomson, S.J., Fiers, M.W.E.J., . . A Allan, A.C. (2010). Identificati- on of Mendel's White Flower Character. PLoS ONE, 5(10), 13230. doi: $10.1371 /$ journal.pone. 0013230

Kneen, B.E., \& LaRue, T.A. (1988). Induced symbiosis mutants of pea (Pisum sativum) and sweetclover (Melilotus albus annua). Plant Sci, 58, 177-182.

Kondykov, I.V., Zotikov, V.I., Zelenov, A.N., Kondykova, N.N., \& Uvarov, V.N. (2006). Biology and breeding of determinate pea forms. Orel: Kartush. In Russian.

Krusell, L., Sato, N., Fukuhara, I., Koch, B.E.V., Grossmann, C., Okamoto, S., ... Parniske, M. (2011). The CLAVATA2 genes of pea and Lotus japonicus affect autoregulation of nodulation. Plant Journal, 65(6), 861-871.

Kumar, S., Chaudhary, S., Sharma, V., Kumari, R., Mishra, R.K., Kumar, A., ... Kumar, A. (2010). Genetic control of leaf-blade morphogenesis by the INSECATUS gene in Pisum sativum.J Genet, 89, 201-211.

Lamprecht, H. (1947). The inheritance of the number of flowers per inflorescence and the origin of Pisum, illustrated by polymeric genes. Agri Hort Genetica, 5, 16-25.

Lester, D.R., Ross, J.J., Davies, P.J., \& Reid, J.B. (1997). Mendel's stem length gene (Le) encodes a gibberellin 3.beta.-hydroxylase. Plant Cell, 9(8), 1435-1443.

Li, X., Zhuang, L., Ambrose, M., Rameau, C., Hu, X., Yang, J., \& Luo, D. (2010). Genetic analysis of ele mutants and comparative mapping of ele 1 locus in the control of organ internal asymmetry in garden pea. $J$ Integr Plant Biol,52, 528-535.

Makasheva, R.K. (1984). The pea. New Delhi: Oxonian Press.

Makasheva, K.R., \& Drozd, A.M. (1987). Determinate growth habit (det) in peas: Isolation, symbolization and linkage. (pp. 31-32).

Marx, G.A. (1987). A suite of mutants that modify pattern formation in pea leaves. Plant Mol Biol Report, 5(3), 311-335. doi:10.1007/BF02668994

Mendel, G. (1866). Versuche ueber Pflanzenhybriden. Verhandl Naturfosch Vereins, 4, 3-47.

Mikić, A., Mihailović, V., Ćupina, B., Kosev, V., Warkentin, T., Mcphee, K., . . . Ellis, N. (2011). Genetic background and agronomic value of leaf types in pea (Pisum sativum). Ratar Povrt, 48, 275-284. doi:10.5937/ratpov1102275M

Mishra, R.K., Chaudhary, S., Kumar, A., \& Kumar, S. (2009). Effects of MULTIFOLIATE-PINNA, AFILA, TENDRILLESS and UNIFOLIATA genes on leafblade architecture in Pisum sativum. Planta, 230(1), 177-190.

Moreau, C., Ambrose, M.J., Turner, L., Hill, L., Ellis, N.T.H., \& Hofer, J.M.I. (2012). The b gene of pea encodes a defective flavonoid 3',' '-hydroxylase, and confers pink flower color. Plant Physiology, 159(2), 759-768.

Murphet, I.C., \& Reid, J.B. (1993). Developmental mutants. In R. Casey \& D.R. Davies (Eds.), Peas: Genetics, molecular biology and biotechnology. (pp. 165-216). Oxfordshire: CAB International.

Nadeau, J.A., \& Sack, F.D. (2002). Stomatal development of Arabidopsis. In The Arabidopsis book. doi:10.1199/tab.0066

PGene Pisum Gene List. John Innes Center Germplasm Collection Retrieved from http://http://data.jic.bbsrc.ac.uk/cgi-bin/ pgene 2013 May 8.

Prajapati, S., \& Kumar, S. (2002). Interaction of the UNIFOLIATA-TENDRILLED ACACIA gene with AFILA and TENDRIL-LESS genes in the determination of leaf blade growth and morphology in pea Pisum sativum. Plant Science, 162(5), 713-721.

Reid, J.B., \& Ross, J.J. (2011). Mendel's genes: toward a full molecular characterization. Genetics, 189(1), 3-10.

Ross, J.J., Murfet, I.C., \& Reid, J.B. (1997). Gibberellin mutants. Physiologia Plantarum, 100(3), 550-560. doi:10.1111/ j.1399-3054.1997.tb03060.x

Sattler, R. (1988). Homeosis in Plants. American Journal of Bota$n y, 75(10)$, 1606-1617. doi:10.2307/2444710 
Sharma, V., Tripathi, B.N., \& Kumar, S. (2012). Organ-wise homologies of stipule, leaf and inflorescence between Pisum sativum genetic variants, Delonix regia and Caesalpinia bonduc indicate parallel evolution of morphogenetic regulation. Plant Syst Evol, 298, 1167-1175.

Sharma, V., Chaudhary, S., Kumar, A., \& Kumar, S. (2012). COCHLEATA controls leaf size and secondary inflorescence architecture via negative regulation of UNIFOLIATA (LEAFY ortholog) gene in garden pea Pisum sativum. Journal of Biosciences, 37(Suppl.1), 1041-1059.

Shtark, O., Provorov, N., Mikić, A., Borisov, A., Ćupina, B., \& Tikhonovich, I. (2011). Legume root symbioses: natural history and prospects for improvement. Ratar Povrt, 48, 291-304. doi: $10.5937 /$ ratpov1102291S

Singer, S.R., Hsiung, L.P., \& Huber, S.C. (1990). Determinate (det) mutant of Pisum sativum (Leguminosae: Papilionoideae) exhibits an indeterminate growth pattern. Am J Bot, 77, 13301335.

Singer, S., Sollinger, J., Maki, S., Fishbach, J., Short, B., Reinke, C., ... Mullen, H. (1999). Inflorescence architecture: A developmental genetics approach. Botanical Review, 65(4), 385-410. doi: $10.1007 / \mathrm{BF} 02857756$

Sinjushin, A. (2011). On the role of genes DETERMINATE, LATE FLOWERING and FASCIATA in the morphogenesis of pea inflorescence. Ratar Povrt, 48, 313-320. doi:10.5937/ ratpov1102313S

Sinjushin, A. (2013). Origin and variation of polymerous gynoecium in Fabaceae: evidence from floral mutants of pea (Pisum sativum L.). Plant Syst Evol. In press. doi 10.1007/s00606-013 $-0915-6$.

Sinjushin, A.A., \& Gostimsky, S.A. (2006). Fasciation in pea: basic principles of morphogenesis. Rus J Dev Biol, 37, 375-381.

Sinjushin, A.A., \& Gostimskii, S.A. (2007). Relationship between different fasciated lines of pea. Pisum Genet, 39, 16-18.
Sinyushin, A.A. (2010). Flower fasciation: I. Origin of enlarged meristem. Moscow Uni Biol Sci Bull, 65, 98-103.

Tattersall, A.D., Turner, L., Knox, M.R., Ambrose, M.J., Ellis, N.T.H., \& Hofer, J.M.I. (2005). The mutant crispa reveals multiple roles for PHANTASTICA in pea compound leaf development. Plant Cell, 17(4), 1046-1060. doi:10.1105/ tpc. 104.029447

Taylor, S., Hofer, J., \& Murfet, I. (2001). Stamina pistilloida, the pea ortholog of Fim and UFO, is required for normal development of flowers, inflorescences, and leaves. Plant Cell, 13(1), 31-46.

Varshney, R.K., Song, C., Saxena, R.K., Azam, S., Yu, S., Sharpe, A.G., . . Iwata, A. (2013). Draft genome sequence of chickpea (Cicer arietinum) provides a resource for trait improvement. Nature Biotechnology, 31(3), 240-246.

Wang, Z., Luo, Y., Li, X., Wang, L., Xu, S., Yang, J., ... Luo, D. (2008). Genetic control of floral zygomorphy in pea (Pisum sativum L.). Proc Natl Acad Sci, 105, 10414-10419.

Weeden, N.F., Brauner, S., \& Przyborowski, J.A. (2002). Genetic analysis of pod dehiscence in pea (Pisum sativum L.). Cell Mol Biol Lett, 7(2B), 657-663.

Weigel, D., \& Meyerowitz, E.M. (1994). The ABCs of floral homeotic genes. Cell, 78(2), 203-9.

White, O.E. (1948). Fasciation. Botanical Review, 14(6), 319358. doi:10.1007/BF02861723

Zelenov, A.N., Shchetinin, V.Y., \& Sobolev, D.V. (2008). Breeding value of pea form with dissected leaflet. Agrarnaya nau$k a, 2,19-20$. In Russian.

Zhuang, L., Ambrose, M., Rameau, C., Weng, L., Yang, J., Hu, X., ... Li, X. (2012). LATHYROIDES, Encoding a WUSCHEL-Related Homeobox1 Transcription Factor, Controls Organ Lateral Growth, and Regulates Tendril and Dorsal Petal Identities in Garden Pea (Pisum sativum L.). Molecular Plant, 5(6), 1333-1345.

\title{
Genetika mutacije graška (Pisum sativum L.): Šta je urađeno i šta treba da se uradi
}

\author{
Andrey Sinjushin
}

Sažetak: Pored izuzetne praktične vrednosti, baštenski grašak (Pisum sativum L.) predstavlja klasični model za proučavanje ontogeneze složene cvasti, složenog lista, zigomorfnog cveta i nodulacije. Proširen niz prirodnih varijacija mutacijama omogućio je unapređenje useva i razvojnih istraživanja. Dat je pregled trenutnog stanja genetike mutacije kod graška sa posebnim osvrtom na genetiku ontogeneze i praktičnu vrednost.

Ključne reči: genetika, grašak, mutacija, ontogeneza, Pisum sativum 